\title{
Simultaneous occurrence of transient resolving thyrotoxicosis due to painless thyroiditis, hypopituitarism and diabetes insipidus following pituitary apoplexy
}

\author{
Haruka Sasaki, Osamu Ohnishi, 'Toshio Okudera and Makoto Okumura
}

\author{
Departments of Internal Medicine and ${ }^{1}$ Radiology, School of Medicine, Fukuoka University, Fukuoka \\ 814-01, Japan.
}

\begin{abstract}
Summary: A rare case of concomitant association of transient thyrotoxicosis due to painless thyroiditis, hypopituitarism and central diabetes insipidus following spontaneous pituitary apoplexy is presented.
\end{abstract}

\section{Introduction}

Pituitary apoplexy is characterized by a wide spectrum of clinical features, not only in mode of presentation but also in outcome. ${ }^{1-3}$ We treated a patient with a previously undiagnosed pituitary tumour in whom spontaneous pituitary apoplexy occurred. Subsequently, impairments of both anterior and posterior pituitary function and transient resolving thyrotoxicosis secondary to painless (silent) thyroiditis ${ }^{4,5}$ developed. To our knowledge, these events concomitant with pituitary apoplexy have not been previously reported.

\section{Case report}

A 61 year old post-menopausal Japanese housewife was admitted to Fukuoka University Hospital in May, 1986 with marked general malaise, polydipsia and weight loss which had became progressively worse during a 4-month period. She had experienced the abrupt onset of severe headache associated with nausea and blurring vision with diplopia. The visual disturbance and headache gradually improved but 3 weeks prior to admission she had a recurrent attack of headache and transient fever $\left(38.5^{\circ} \mathrm{C}\right)$. Menarche was at age 15 years and the menopause at 45. Galactorrhea occurred on one occasion only at the age of 55. There was no personal or family history of thyroid or autoimmune disease. She had not ingested excessive amounts of iodine or thyroid hormone.

On admission, she was alert and oriented, but

Correspondence: Haruka Sasaki, M.D., Institute of Health Science, Kyushu University, 6-1, Kasuga-Koen, Kasuga 816, Japan

Accepted: 2 July 1990 distressed by marked general fatigue. Physical examinations revealed a fine tremor, dry skin and nervousness. She had no thyroid enlargement or tenderness, exophthalmos or galactorrhoea. Her blood pressure was $105 / 64 \mathrm{mmHg}$ with variable sinus tachycardia ( $92-105$ beats $/ \mathrm{min})$. Visual field perimetry was also intact. Routine laboratory studies were negative except for a low serum protein $(51 \mathrm{~g} / \mathrm{l})$, hypocholesterolaemia (1.90-2.22 $\mathrm{mmol} / \mathrm{l})$, hypernatraemia $(143-151 \mathrm{mmol} / \mathrm{l})$ and low specific gravity of urine. Test for $\mathrm{C}$-reactive protein was negative and the erythrocyte sedimentation rate was $12 \mathrm{~mm} / \mathrm{h}$.

An impairment in corticotrophin secretion was suspected from the low plasma cortisol (27.6 $\mathrm{nmol} / \mathrm{l}$ at $08.00 \mathrm{~h}$; normal $110-520 \mathrm{nmol} / \mathrm{l}$ ) and the low urinary excretion of 17-hydroxycorticosteroids $(1.1 \mathrm{mg} /$ day; normal $1.9-6.1 \mathrm{mg} /$ day) and $17-\mathrm{ket}-$ osteroids $(0.6 \mathrm{mg} /$ day; normal $3.1-8.8 \mathrm{mg} /$ day $)$, and an appropriate response to the rapid ACTH (Cortrosyn) test. Plasma ACTH and cortisol responses to ovine corticotrophin releasing hormone (ovine CRF: $100 \mu \mathrm{g}$, i.v.) also were diminished. Basal level of growth hormone $(<0.3 \mu \mathrm{g} / \mathrm{l} ;$ normal $<5.0 \mu \mathrm{g} / \mathrm{l})$, somatomedin $\mathrm{C}(0.14 \mathrm{U} / \mathrm{ml}$; normal 0.3 to $3.0 \mathrm{U} / \mathrm{ml}$ ) and gonadotrophin $(\mathrm{LH} 3.9 \mathrm{IU} / 1$ and FSH $<1.9 \mathrm{IU} / \mathrm{l})$ were also low, and responses to stimulation tests [Insulin-stress, L-dopa and luteinizing hormone releasing hormone (LH-RH)] were all blunted. Although an X-ray of the skull revealed no abnormalities, brain computed tomographic (CT) scan and magnetic resonance imaging (MRI) demonstrated a suprasellar mass that, after infusion, developed a peripheral ring-like enhancement $^{6}$ and a large hyperintense pituitary mass, ${ }^{7}$ respectively (Figure 1a,b).

A diagnosis of pituitary apoplexy associated with anterior pituitary failure was made. However, 


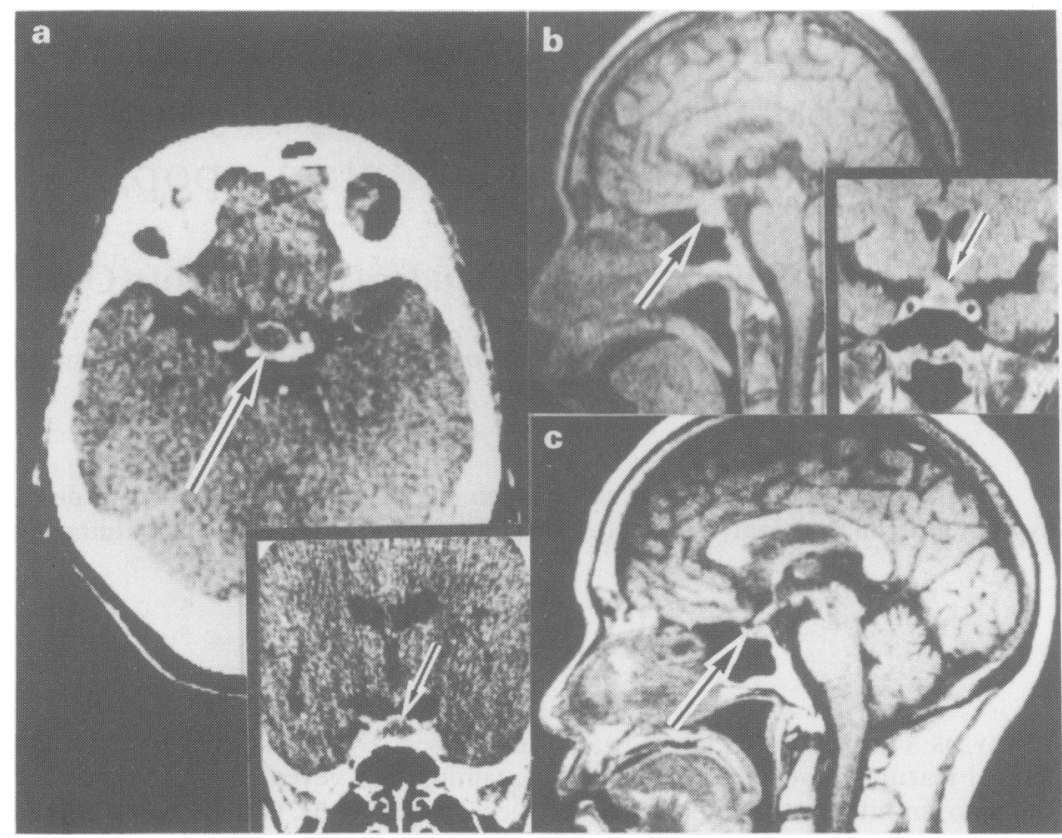

Figure 1 (a) Postcontrast computerized tomogram (transverse and coronal). Ring-like peripheral enhancement of suprasellar extension of the tumour (arrow) is the necrotic pituitary tissue (June 1986). (b) Sagittal and coronalo $\mathrm{Tl}$-weighted magnetic resonance imaging (MRI) scans showed increased signal intra- and suprasellar pituitary tumour, Inset: coronal section showing elevation of the optic chiasma (June 1986). (c) T1-weighted MRI showing spontaneous reduction of the intra- and suprasellar pituitary mass after 1 year (June 1987).

the initial levels of thyroid hormones were elevated, as follows: total thyroxine (T4) $212.4 \mathrm{nmol} / \mathrm{l}$ (normal 59.2 to $157.0 \mathrm{nmol} / \mathrm{l})$, free triiodothyronine (T3) $7.6 \mathrm{pg} / \mathrm{ml}$ (normal 3.0 to $5.8 \mathrm{pg} / \mathrm{ml}$ ), free.T4 $42.5 \mathrm{pmol} / \mathrm{l}$ (normal 10.9 to $28.9 \mathrm{pmol} / \mathrm{l}$ ), T3 resin uptake 0.41 litres (normal 0.23 to 0.35 litres) and suppressed thyroid stimulating hormone (TSH) to less than $0.3 \mathrm{mU} / 1$ (normal 0.30 to $4.0 \mathrm{mU} / 1$ ). TSH responses to thyrotrophin releasing hormone (TRH: $500 \mu \mathrm{g}$, i.v.) were all suppressed (all $<1.3$ $\mathrm{mU} / \mathrm{l}$ ). Basal prolactin (PRL) was slightly elevated $(120-150 \mu \mathrm{g} / \mathrm{l} ;$ normal $<30 \mu \mathrm{g} / \mathrm{l})$ and the response to TRH was adequate (peak $260 \mu \mathrm{g} / 1$ at $60 \mathrm{~min}$ ). The anti-TSH receptor antibody (measured by thyrotrophin binding inhibiting immunoglobulin: TBII) was $-6.9 \%$ (normal $< \pm 10 \%$ ) and antipituitary antibodies (indirect immunofluorescence technique using rat pituitary $\mathrm{GH} 3$ cell and mouse pituitary AtT20 cell as the antigen $)^{8}$ were negative. Both anti-thyroglobulin antibody (TGHA) and anti-microsomal antibody (MCHA) (haemagglutination assay) were repeatedly positive at the titres $1: 200$ to $1: 400$ and $1: 800$ to $1: 2,560$ (normal, both $<$ 1:100), respectively. A thyroid scan with ${ }^{99 \mathrm{~m}} \mathrm{Tc}$ revealed no uptake in the thryoid area.
These findings led to the diagnosis of 'painless (silent) thyroiditis' with thyrotoxicosis. ${ }^{4,5}$ Within 3 weeks, she was biochemicaily euthyroid, while on no medication (free $\mathrm{T} 33.7 \mathrm{pg} / \mathrm{ml}$ and free $\mathrm{T} 4$ $21.4 \mathrm{pmol} / \mathrm{l})$. Four weeks later, the thyroid hormone levels markedly fell to severe hypothyroid ranges (free T3 $1.8 \mathrm{pg} / \mathrm{ml}$, free T4 $8.1 \mathrm{pmol} / \mathrm{l}$ and TSH $<1.3 \mathrm{mU} / \mathrm{l})$. At that time repeated radioactive ${ }^{99 m}$ Tc uptake had risen despite a low uptake. Before replacement, the 24- ${ }^{123}$ I uptake was $33.7 \%$ (normal 10 to $40 \%$ ). Repeated TRH stimulation resulted in a delayed response in plasma TSH, as noted in hypothalamic disorders ${ }^{9}$ (basal $5.1 \mathrm{mU} / 1$ and peak TSH $17.0 \mathrm{mU} / 1$ at $90 \mathrm{~min}$ ). Hydrocortisone $(25 \mathrm{mg} /$ day $)$ and subsequent L-thyroxine (50-100 $\mu \mathrm{g} / \mathrm{day})$ were given, with marked improvement in the general clinical condition.

When hydrocortisone was substituted, daily urine output abruptly increased to about 8 to 9 litres with low osmolality (less than $200 \mathrm{mmol} / \mathrm{kg}$ ) and diabetes insipidus was suspected (so-called masked diabetes insipidus due to rapid development of hypopituitarism). ${ }^{2}$ After water deprivation for $8 \mathrm{~h}$, plasma osmolality rose to $291 \mathrm{mmol} / \mathrm{kg}$, but the urine osmolality remained low $(231 \mathrm{mmol} /$ 
$\mathrm{kg}$ ). Plasma antidiuretic hormones (ADH) were not elevated (all $<1.0 \mathrm{pg} / \mathrm{dl}$; normal $<7.5 \mathrm{pg} / \mathrm{dl}$ ). With the administration of $5.0 \mathrm{U}$ of pitressin, the urine osmolality rapidly increased $(490 \mathrm{mmol} / \mathrm{kg})$. A diagnosis of central diabetes insipidus was confirmed. The urine volume was controlled by treatment with intranasal desmopressin (10 to $15 \mu \mathrm{g}$ /day). Plasma PRL decreased gradually to normal ranges during 1 year from onset and there was a concomitant regression of the pituitary mass associated with partial arachnoid herniation of cerebrospinal fluid into the sella (partial empty sella) on CT and MRI ${ }^{10,11}$ (Figure 1c). She is currently well and is being followed in the outpatient clinic on L-thyroxine $(125 \mu \mathrm{g} /$ day $)$, hydrocortisone $(20 \mathrm{mg} /$ day $)$ and desmopressin $(10 \mu \mathrm{g} /$ day).

\section{Discussion}

Pituitary apoplexy is becoming increasingly recognized as a complication of pituitary adenomas, occurring in over $10 \%$ of cases. ${ }^{1,3}$ Manifestations typically include headache, meningeal irritation, and visual loss or ophthalmoplegia, or both, with additional features depending on the extent of spread of hypophyseal contents and haemorrhage. Multiple pituitary hormone deficiencies and/or resolution of excessive hormonal production occur in most patients with non-functioning or functioning pituitary adenomas. However, diabetes insipidus due to damage of the posterior pituitary

\section{References}

1. Cardoso, E.R. \& Peterson, E.W. Pituitary apoplexy: a review. Neurosurgery 1984, 14: 363-373.

2. Veldhuis, D.J. \& Hammond, J.M. Endocrine function after spontaneous infarction of the human pituitary. Report, review, and reappraisal. Endocrinol Rev 1980, 1: 100-109.

3. Reid, R.L., Quigley, M.E. \& Yen, S.S.C. Pituitary apoplexy. A review. Arch Neurol 1985, 42: 712-719.

4. Woolf, P.D. Transient painless thyroiditis: A variant of lymphocytic thyroiditis? Endocrinol Rev 1980, 1: 411-420.

5. Amino, N., Iwatani, Y., Tamaki, H., Mori, H., Aozasa, K. \& Miyai, K. Postpartum autoimmune thyroid syndromes. In: Walfish, P.G., Wall, J.R. \& Volpe, R. (eds) Autoimmunity and the Thyroid. Academic Press, Florida, 1985, pp. 289-314.

6. Post, M.J.D., David, N.J., Glaser, J.S. \& Safran, A. Pituitary apoplexy diagnosis by computer tomography. Radiology 1980, 134: 665-670.

7. Lacomis, D., Johnson, L.N. \& Mamourian, A.C. Magnetic resonance imaging in pituitary apoplexy. Arch Ophthalmol 1988, 106: 207-209.

8. Sugiura, M., Hashimoto, A., Shizawa, M. et al. Detection of antibodies to anterior pituitary cell surface membrane with insulin dependent diabetes mellitus and adrenocorticotropic hormone deficiency. Diabetes Res 1987, 4: 63-66. and/or hypothalamus, either transient or permanent, is a rare sequela of pituitary apoplexy. ${ }^{2,3}$

Our patient had not only hypopituitarism and diabetes insipidus but also transient thyrotoxicosis secondary to painless thyroiditis probably as a consequence of pituitary apoplexy. One may presume that their coexistence may be fortuitous. This patient, however, had persistently positive thyroid autoantibodies, a past-history of galactorrhea and a moderate elevation of plasma PRL thereby suggesting the pre-existing subclinical autoimmune thyroiditis and PRL producing pituitary tumour. The pathogenesis and/or trigger of spontaneous painless thyroiditis is unknown, but there is evidence of underlying changes of immune reactions related to autoimmune thyroiditis. ${ }^{4,5}$ Simultaneous occurrence of autoimmune Addison's disease and painless thryoiditis has been reported. ${ }^{12}$ In this patient, primary adrenal failure was ruled out by appropriate responses to ACTH test and other endocrine functions. Maruyama et al.$^{13}$ reported painless thyroiditis occurring after cessation of steroid therapy in a patient with autoimmune thyroiditis and rheumatoid arthritis. More recently, Haraguchi and colleagues ${ }^{14}$ reported painless thyroiditis occurring after unilateral adrenalectomy in two patients with Cushing's syndrome. In our patient, the pathogenic trigger for painless thryoiditis may have been immunological changes (immune rebound phenomenon) ${ }^{5}$ due to rapid development and/or progression of secondary adrenal failure after pituitary apoplexy.
9. Hall, R., Ormston, B.J., Besser, G., Cryer, R.I.. \& McKendrick, $M$. The thyrotrophin releasing hormone in disease of the pituitary and hypothalamus. Lancet 1972, i: 759-763.

10. Montalban, J., Sumalla, J., Fernandez, J.L., Molins, A., Simo, R. \& Codina, A. Empty sella syndrome and pituitary apoplexy (correspondence). Lancet 1988, i: 774.

11. Anonymous. Pituitary tumors and the empty sella syndrome. (Editorial) Lancet 1986, ii: $1371-1372$.

12. Paker, M., Klein, I., Fishman, L.M. \& Levey, G.S. Silent thyrotoxic thyroiditis in association with chronic adrenocortical insufficiency. Arch Intern Med 1980, 140: 1108-1109.

13. Maruyama, H., Kato, M., Mizuno, O. et al. Transient thyrotoxicosis occurred after cessation of steroid therapy in a patient with autoimmune thyroiditis and rheumatoid arthritis. Endocrinol Jpn 1982, 29: 583-588.

14. Haraguchi, K., Hiramatus, K. \& Onaya, T. Transient thyrotoxicosis after unilateral adrenalectomy in two patients with Cushing's syndrome. Endocrinol Jpn 1984, 31: 577-582. 